\title{
DA BIOLOGIA MOLECULAR À MEDICINA: MÉTODOS COMUMENTE UTILIZADOS EM FARMACOGENÉTICA
}

\author{
FROM MOLECULAR BIOLOGY TO MEDICINE: METHODS COMMONLY USED IN PHARMACOGENETICS
}

Mario Hiroyuki Hirata ${ }^{1}$, Vladimir Tavares ${ }^{2}$, Rosario Dominguez Crespo Hirata ${ }^{1}$

1Docentes. ${ }^{2}$ Doutor do Programa de Pós-Graduação em Farmácia - Analises Clinicas. Departamento de Análises Clínicas e Toxicológicas. Faculdade de Ciências Farmacêuticas - USP.

Correspondência: Prof. Dr. Mario H. Hirata. Av. Prof. Lineu Prestes, 580 B. 17,

CEP 05508-900 São Paulo - SP. Tel.: (11) 3091-3634 - FAX: (11) 3813-2197 - E-mail: mhhirata@usp.br

Hirata $\mathrm{MH}$, Tavares V, Hirata RDC. Da biologia molecular à medicina: métodos comumente utilizados em farmacogenética. Medicina (Ribeirão Preto) 2006; 39 (4): 522-34.

RESUMO: Nesta revisão, foram discutidos os procedimentos para obtenção, manuseio e armazenamento de amostras biológicas úteis em testes moleculares. Métodos para triagem e detecção direta de mutações e polimorfismos genéticos foram apresentados. Os princípios, estratégias, aplicações e limitações de variações da reação em cadeia pela polimerase (PCR), tais como eletroforese em gel com gradiente de desnaturação (DGGE), polimorfismo de conformação de fita simples (SSCP), polimorfismo de tamanhos de fragmentos de restrição (RFLP), amplificação alelo oligonucleotídeo-específica (PCR-ASO), PCR em tempo real PCR, arranjos de DNA e outras técnicas moleculares, foram comentados.

Descritores: Farmacogenética. Reação em Cadeia da Polimerase. Polimorfismo Conformacional de Simples Fita. Polimorfismo de Fragmento de Restrição. DNA- Arranjos. Eletroforese em Gradiente em Gel Desnaturante.

\section{ABREVIATURAS}

PCR, reação em cadeia pela polimerase Southern blot, técnica de transferência de DNA

RFLP, polimorfismo de tamanhos de fragmentos de restrição

SDS, duodecil sulfato de sódio

DEPC, dietilpirocarbonato

DGGE, eletroforese em gel com gradiente de desnaturação

SSCP, polimorfismo de conformação de fita simples

HDA, análise de heteroduplex

CCM, método da clivagem química

PTT, teste da proteína truncada

PCR-ASO, amplificação alelo oligonucleotídeoespecífica

\section{1- INTRODUÇÃO}

A procura pela terapêutica individualizada e com o menor risco de efeitos indesejáveis ou colaterais sempre foi uma meta dos médicos, farmacologistas, farmacêuticos. Para isso têm sido pesquisadas novas formas e formulações farmacêuticas procurando aumentar a eficácia e reduzir a toxicidade dos medicamentos. No entanto, até recentemente, os estudos dirigidos com abordagem genética de pacientes foram pouco explorados. A descrição da sequiência completa do genoma humano trouxe perspectivas de aplicações potenciais das informações do genoma, transcriptoma e proteoma para o estudo de novos alvos terapêuticos e da possibilidade, em um futuro breve, de uso da medicação individualizada.

A abordagem de métodos utilizados no estudo 
da farmacogenética será realizada de forma sucinta e clara para facilitar a compreensão e estimular o leitor a ampliar seu conhecimento procurando textos mais específicos e aprofundados em cada tema apresentado. Os assuntos estão divididos em tópicos que abrangem procedimentos de obtenção de amostras, métodos extração de ácidos nucléicos e métodos de triagem de mutações e de estudo de polimorfismos genéticos.

\section{2- PROCEDIMENTOS DE OBTENÇÃO DE AMOSTRAS}

Os procedimentos de obtenção de amostras biológicas são parte da fase pré-analítica dos estudos farmacogenéticos. Nessa fase, são obtidas informações sobre indivíduo que está participando do estudo que incluem o tipo de material biológico a ser coletado, horário de coleta, procedimento de coleta do material, forma de transporte e armazenamento da amostra, além de dados pessoais como sexo, idade, etnia, dieta, uso de medicamentos e outras características necessárias para análise dos resultados. Estas informações direcionarão a maneira que deve ser obtida e conservada, para que ao proceder a análise não se tenha dúvida do resultado que possa ser gerado nos processo analítico.

$\mathrm{Na}$ fase pré-analítica, é primordial que se verifiquem os tipos testes a serem realizados e o ácido nucléico a ser isolado para utilizar os procedimentos mais adequados de conservação e armazenamento para manter a integridade da amostra biológica ${ }^{1}$. É importante ter em mente que os cuidados no processamento de amostras para obtenção de DNA são distintos dos utilizados para a extração de RNA. Para o isolamento de DNA, as amostras biológicas podem ser refrigeradas em temperaturas que variam entre 4 a $10^{\circ} \mathrm{C}$. Por outro lado, para a análise de RNA as amostras devem ser imediatamente conservadas em temperatura ultrabaixa $\left(-70\right.$ a $\left.-80{ }^{\circ} \mathrm{C}\right)$, exceto se a extração do RNA for realizada imediatamente. Recomenda-se também a adição de um conservante de RNA na amostra a ser armazenada, geralmente fornecido comercialmente.

Uma outra observação importante nesta etapa é a escolha do material descartável a ser utilizado para a conservação da amostra, se for conservada em nitrogênio líquido, ou em congelador de ultra-baixa temperatura, os tubos a serem utilizados devem ser resistentes nessa temperatura e ter tampa de rosca com anel de vedação, de boa procedência, e isentos de RNAse e DNAses.

As amostras de tecidos a serem utilizadas para estudos histológicos ou "in situ” devem ser congela- das no criostato do micrótomo e imediatamente processadas e transferidas para tubos termo-resistentes, mantidos em gelo seco, se possível com conservante para RNA. A seguir, os tubos devem ser armazenados a $-80^{\circ} \mathrm{C}$. Caso a amostra tiver que ser emblocada em parafina para estudos anatomo-patológicos, o material biológico deve ser mergulhado em formol (de boa procedência) tamponado com tampão fosfato em $\mathrm{pH}=7,0$ a 7,4, recém preparado. Ressalta-se a importância da averiguação da pureza do formol, pois quando se encontra armazenado de forma inadequada, pode conter excesso de ácido fórmico que degrada os ácidos nuclécos. Ao se utilizar a solução de formol, devese vaporizar nitrogênio dentro do frasco e fechar hermeticamente para aumentar a estabilidade do formol.

As amostras de células em cultura podem ser armazenadas para análise futura, em tubos termo-resistente, com uma prévia lavagem das células em tampão fosfato $\mathrm{pH} 7,4 \mathrm{e}$, posteriormente em tampão TrisEDTA, pH 8,0.

Amostras de órgãos como fígado, rins, coração, entre outros que retém volume de sangue relativamente grande devem ser rapidamente limpos por perfusão com salina tamponada gelada e o excesso de salina e membranas aderidas devem ser rapidamente retiradas. As amostras devem ser congeladas imediatamente em nitrogênio liquido e armazenadas em congelador $-70^{\circ} \mathrm{C}$.

Amostras de sangue periférico podem ser colhidas com o anticoagulante EDTA ou citrato. Para extração de DNA a amostra pode ser conservada apenas em temperatura de $4{ }^{\circ} \mathrm{C}$ a $10^{\circ} \mathrm{C}$. Amostras de coágulo também podem ser utilizadas para extração de DNA, mas devem ser armazenadas a $-20{ }^{\circ} \mathrm{C}$ antes do processamento.

\section{3- MÉTODOS DE EXTRAÇÃo DE ÁCIDOS NUCLEICOS}

Os estudos genéticos requerem ácidos nucléicos íntegros e isento de contaminantes e interferentes que possam prejudicar os testes moleculares. Métodos como a reação em cadeia pela polimerase (PCR), a técnica de transferência de DNA (Southern blot) e outros utilizados no estudo de polimorfismo de tamanhos de fragmentos de restrição (RFLP) podem sofrer interferências significativas se a obtenção do DNA estiver comprometida.

Os métodos de isolamento e purificação dos ácidos nucléicos consistem de três etapas: (1) lise das células e solubilização do DNA ou RNA; (2) método 
enzimático ou químico para remover as proteínas contaminantes e outras macromoléculas; e (3) precipitação alcoólica para isolamento do $\mathrm{DNA}^{2}$. Os protocolos básicos geralmente são aplicáveis a uma ampla variedade de materiais.

\section{1- Extração de DNA genômico de leucócitos}

A extração de DNA dos leucócitos humanos tornou-se uma realidade nos laboratórios que estudam doenças genéticas. Os métodos atualmente disponíveis possibilitam recuperar o DNA de alto peso molecular, sendo simples, rápidos e econômicos com rendimentos adequados para uso rotineiro.

$\mathrm{O}$ protocolo mais adequado à rotina laboratorial para avaliação de polimorfismos e mutações genéticas compreende a lise celular com detergentes, remoção das proteínas por precipitação com cloreto de sódio concentrado (salting-out) e isolamento do DNA genômico por precipitação etanólica ${ }^{3}$. A utilização de detergentes, como Triton X-100 e duodecil sulfato de sódio (SDS), evita o uso de solventes orgânicos perigosos e o alto custo e demorada digestão da proteínase K. O rendimento e a integridade do DNA extraído são excelentes quando comparados com os de outros métodos de extração. O DNA é apropriado para as técnicas moleculares como a PCR e RFLP. Atualmente são utilizados produtos comerciais disponíveis no mercado que minimizam erros de procedimentos resultantes de reagentes produzidos no laboratório.

\section{2- Extração de DNA genômico de tecidos e células}

O método básico compreende a ruptura do tecido com um homogeinizador, a lise celular com o detergente iônico SDS, extração fenólica das proteínas (atualmente se substitui por cromatografia de afinidade) e precipitação etanólica do DNA. Este método é útil para preparação de DNA genômico de muitas amostras de tecido ou de linhagens celulares, com um mínimo de consumo de tempo e trabalho. O DNA genômico produzido é adequado para amplificação pela PCR ou para a digestão com enzimas de restrição e análise de transferência de DNA. Uma quantidade substancial de RNA acompanha o DNA genômico, o que dificulta a quantificação por espectroscopia no UV. Para eliminar o RNA residual, a preparação deve ser tratada com RNase isenta de DNAse que está presente na maioria dos reagentes comerciais.

Outro método compreende a solubilização dos tecidos ou células com SDS que inativa as DNAses endógenas. A proteínase $\mathrm{K}$ é usada para digerir as proteínas celulares, seguidas de digestão com RNase para remover a maioria do RNA celular. O isolamento do DNA segue basicamente o princípio anterior. Este método é adequado para extrair DNA genômico para análise de DNA por Southern blot ou construção de bibliotecas genômicas. Porém não é adequado para extrair DNA de tecidos, pois não há etapa de ruptura do tecido conjuntivo.

\section{3- Extração de RNA de células ou de amostras biológicas}

A maioria dos métodos de extração de RNA é semelhante aos utilizados na obtenção de DNA, exceto que 2,5 volumes de etanol devem ser usados rotineiramente para precipitação do RNA. É essencial que toda água usada diretamente ou nos tampões seja tratada com dietilpirocarbonato (DEPC) para inativar as RNases.

$\mathrm{O}$ método mais adequado para preparar RNA de boa qualidade envolve a solubilização simultânea do tecido ou células e inativação de RNases endógenas na presença de isotiocianato de guanidina, com subsequente isolamento do RNA por centrifugação em gradiente de cloreto de césio. Dois outros métodos que não requerem ultracentrifugação podem ser utilizados: (1) lise com detergente não-iônico para proporcionar um método rápido para preparação de amostras de RNA citoplasmático e (2) lise celular com isotiocianato de guanidina, remoção das proteínas pela extração fenólica em $\mathrm{pH}$ ácido, seguida de precipitação do $\mathrm{RNA}^{2}$. O segundo método é freqüentemente utilizado para isolamento de genoma dos vírus RNA a partir de amostras biológicas.

A análise e quantificação de RNA total é particularmente importante para os estudos com RNAm. É recomendável que se obtenha RNA com alto índice de pureza, ou seja razão $\mathrm{OD}_{260} / \mathrm{OD}_{280}$ igual ou maior que 1,9 e sem contaminação por DNA ${ }^{2}$. Os métodos de extração de RNA que utilizam colunas de afinidade para RNA e tratamento da amostra com DNase isenta de atividade RNase fornecem RNA total com alto grau de pureza. O RNAm pode ser purificado a partir de preparações de RNA total por cromatografia com oligo-dT celulose.

\section{4- MÉTODOS DE TRIAGEM DE MUTAÇÕES}

Vários métodos para a triagem de mutações de ponto, pequenas deleções ou inserções foram descritos. Para a escolha de um destes métodos, algumas considerações devem ser observadas, tais como: o tipo de ácido nucléico a ser utilizado, o tipo de material biológico 
(sangue periférico, medula óssea, tecidos, secreções ou excreções), o conhecimento ou não da mutação a ser pesquisada, a confiabilidade do método a ser utilizado e que método é mais rápido e economicamente viável.

Um dos métodos moleculares mais utilizados na triagem de mutações é a PCR, reação que possibilita produzir milhares de cópias de segmentos de ácidos nucléicos in vitro utilizando uma enzima DNA polimerase termoestável ${ }^{4}$. A Taq DNA polimerase apresentando índice de erro de incorporação que varia de $10^{-4} \mathrm{a}$ $10^{-5}$ por nucleotídeo, sendo amplamente afetada pelas condições da reação (concentração do cloreto de magnésio, dNTPs, pH e temperatura). Dependendo do método a ser utilizado, os erros da DNA polimerase podem reduzir a especificidade da PCR, particularmente nos casos em que a frequiência de alelos raros é baixa ${ }^{5}$. Embora a probabilidade seja baixa, os erros podem ser interpretados como mutações quando as análises são realizadas com pequeno número inicial de moléculas de DNA molde (<100 moléculas $)^{5}$.

É importante ressaltar que os resultados dos métodos de triagem de mutações devem ser confirmados por seqüenciamento de DNA, pois é um método definitivo para a detecção de mutações ${ }^{6}$.

\section{1- Eletroforese em gel com gradiente de des- naturação (DGGE)}

A triagem de mutações por DGGE (Denaturing Gradient Gel Electrophoresis) é um método no qual a dupla fita de DNA é submetida à eletroforese em gel de poliacrilamida em que utiliza um gradiente de agente desnaturante (uréia ou formamida) ou de temperatura $^{7}$. Nestas condições, ocorre a separação das moléculas de DNA de acordo com sua temperatura de desnaturação ou melting temperature $\left(\mathrm{T}_{\mathrm{m}}\right)$, em segmentos denominados domínios. A dissociação das fitas de DNA em tais domínios resulta em diminuição da mobilidade eletroforética (Figura 1). A diferença de 1 par de bases entre as fitas de DNA (homoduplex) pode alterar a temperatura de desnaturação em $1{ }^{\circ} \mathrm{C}$ ou mais. A falta de complementaridade de bases entre as fitas de DNA (heteroduplex) leva a significante desestabilização desses domínios, resultando em diferenças na $\mathrm{T}_{\mathrm{m}}$ entre homo e heteroduplex acima de $6{ }^{\circ} \mathrm{C}$. Por esta razão, heteroduplex formadas entre fragmentos de alelos comuns e mutantes são geralmente utilizados para a triagem de mutações de ponto (Figura 2).

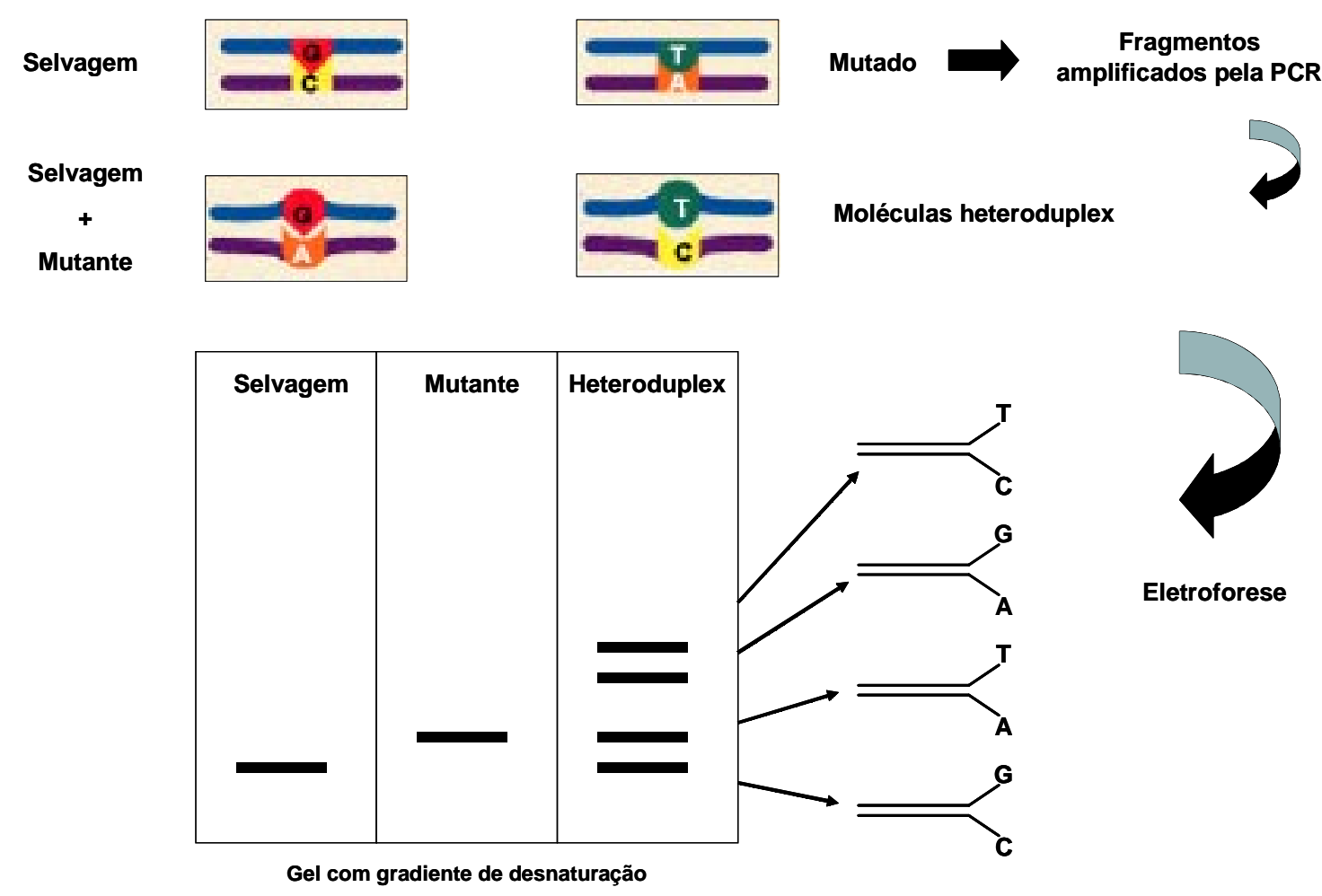

Figura 1. Esquema da triagem de mutações por eletroforese em gel com gradiente de desnaturação (DGGE). 
Para detecção no DGGE, os produtos da PCR são marcados com substâncias radioativas ${ }^{7}$. Atualmente, esse sistema foi substituído por coloração dos produtos com brometo de etídeo ou nitrato de prata.

No método DGGE, podem ser feitas modificações para aumentar o número de domínios a serem analisados. Uma estratégia é o acoplamento sequiências ricas em GC em um dos oligonucleotídeos na PCR

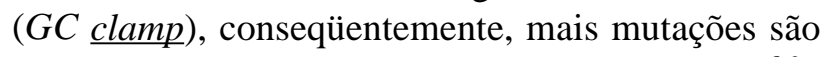
detectadas por DGGE para diferentes finalidades ${ }^{8,9}$.

O tamanho do produto da PCR submetido ao DGGE é de aproximadamente 1000 pares de bases (pb). Com o aumento do número de domínios, a mobilidade diminui, por isto, a fração de mutações detectadas diminui com o aumento do tamanho do fragmento. O limite de detecção do DGGE parece não ser influenciado pela baixa frequiência de alelos mutantes na presença de alta frequencia de alelos comuns.

\section{2- Polimorfismo de conformação de fita sim- ples (SSCP)}

O SSCP (Single-Strand Conformation Polymorphism) é um método de triagem de mutações que permite detectar alterações na mobilidade eletroforética de fitas simples de ácidos nuclécos em condições não-desnaturantes ${ }^{10}$ (Figura 3). As fitas simples de áci-

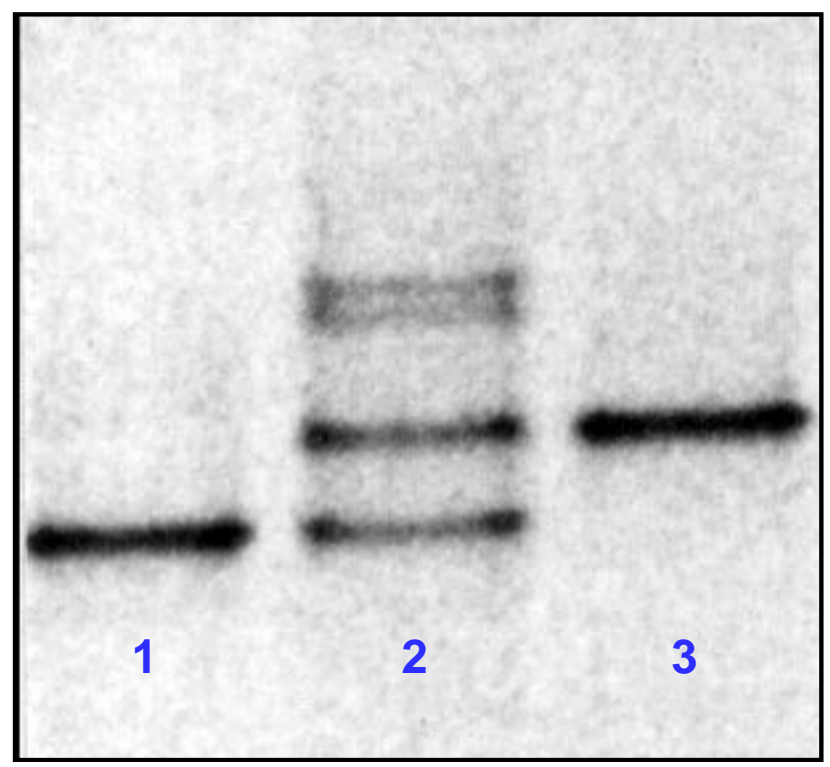

1- Selvagem, 2- Heteroduplex, 3- Mutante

Figura 2. Autorradiograma de produtos da PCR separados por DGGE para a triagem de mutações.

dos nucléicos formam estruturas secundárias em solução que dependem da composição/seqüência de bases e do tamanho da fita simples. Mudança em uma base na seqüência do ácido nucléico amplificado pela PCR pode ser detectada por SSCP. Os perfis de SSCP
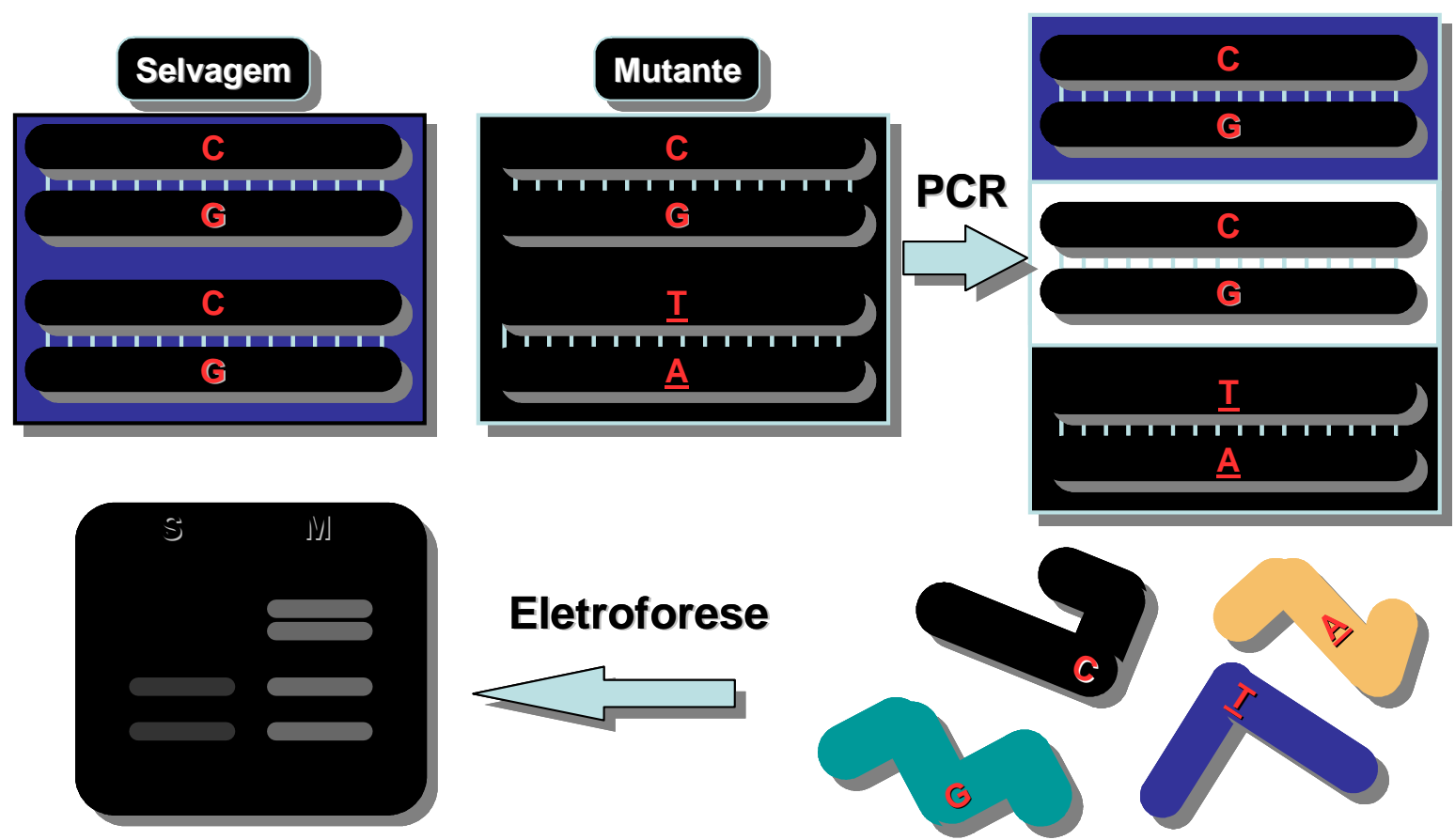

\section{Eletroforese}
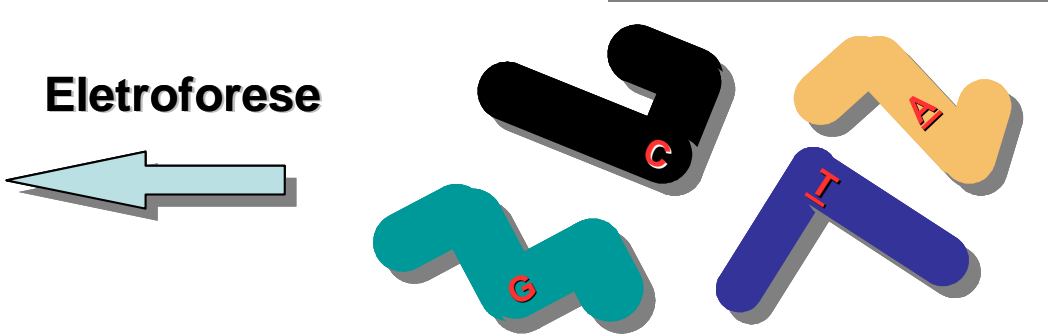

Figura 3. Esquema de triagem de mutações por polimorfismo de conformação de fita simples (SSCP). 
podem ser detectados por autorradiografia marcando-se os produtos da PCR com substâncias radiativas. Atualmente são utilizados os sistemas de detecção por coloração dos géis de eletroforese com nitrato de prata (Figura 4).

O SSCP foi inicialmente descrito para analisar DNA, entretanto, a análise do RNA também é possível $^{11}$. Estruturas secundárias distintas são formadas com maior frequiência pelo RNA do que por moléculas de DNA e fragmentos maiores podem ser analisados. As mutações detectadas por SSCP devem ser confirmadas por sequenciamento de DNA ${ }^{6}$. Além disso, em várias aplicações, sistemas eletroforéticos com géis de tamanhos menores são utilizados em substituição aos sistemas eletroforéticos padronizados para seqüenciamento de $\mathrm{DNA}^{12}$.

A sensibilidade de detecção de mutações por SSCP é maior quando os tamanhos dos produtos da PCR são de 150 a 200 pb $^{13}$. O número de mutações detectáveis diminui quando fragmentos maiores são analisados. A triagem de mutações de produtos maiores sem prejudicar significativamente a sensibilidade do método pode ser alcançada utilizando-se RNA$\mathrm{SSCP}^{11}$.

A eletroforese é realizada em gel de poliacrilamida não-desnaturante. Dependendo da concentração da poliacrilamida, do tamanho do fragmento e da presença de glicerol no gel, o tempo de separação varia de 2 a 6 horas. A resolução é maior em sistemas de géis especiais comercialmente disponíveis ${ }^{14}$. A análise de um fragmento sob diferentes condições pode aumentar o índice de detecção de mutações, sendo que as condições ideais devem ser determinadas empiricamente. $\mathrm{O}$ limite de detecção depende do tamanho do produto da PCR $(<200 \mathrm{pb})$ e da execução da eletroforese em pelo menos duas temperaturas ou dois tampões de eletrodos no sistema eletroforético. Nessas condições 80 a $90 \%$ de mutações são detectáveis por $\mathrm{SSCP}^{15}$.

\section{3- Análise de heteroduplex (HDA)}

A HDA (Heteroduplex Analysis) se fundamenta na separação de fitas híbridas de DNA por sistema eletroforético não-desnaturante ${ }^{16}$. As fitas duplas de DNA (produtos da PCR) de amostras com mutação são desnaturadas por aquecimento e, a seguir, são hibridizadas com amostras sem mutação, formando-se hibridos homoduplex e heteroduplex. As moléculas híbridas são separadas por eletroforese em gel poliacrilamida não-desnaturante, sendo que as moléculas homoduplex e heteroduplex apresentam di-

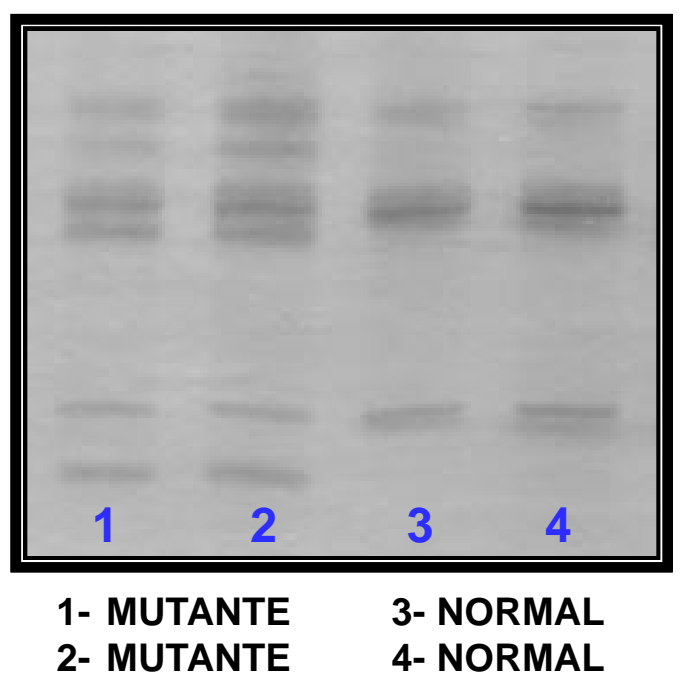

Figura 4. Perfis de SSCP de produtos da PCR separados por eletroforese em gel de poliacrilamida corado com nitrato de prata.

ferentes migrações eletroforéticas (Figura 5). A detecção desses produtos pode ser realizada por coloração com brometo de etídeo ou nitrato de prata.

A resolução de HDA pode ser aumentada utilizando-se géis especiais (MDEC gel) que estão disponíveis comercialmente ${ }^{17}$. Melhor definição das bandas pode ser obtida pela separação das mesmas na presença de uréia (15\%). O tamanho do produto de PCR detectado por HDA varia entre 200 a 600 pb, entretanto, a detecção de mutações para produtos com tamanho acima de $900 \mathrm{pb}$ tem sido realizada ${ }^{15}$.

O limite de detecção de mutações por HDA dependente principalmente da posição e do tipo de base que não apresenta complementaridade. Foram descritas diferentes mutações através da aplicação desta metodologia, com o poder de detecção variando em torno de $80 \%^{16}$. O limite de detecção depende da intensidade do sinal e da separação das heteroduplex e homoduplex.

O tempo de eletroforese em gel de poliacrilamida não-desnaturante pode variar entre 14 a 30 horas, dependendo do tamanho do produto da PCR. O tempo pode ser reduzido utilizando-se eletroforese em capilar $^{18}$.

\section{4- Método da clivagem química (CCM)}

O método CCM (Chemical Cleavage Method) se fundamenta na clivagem de sequiências específicas de DNA heteroduplex por agentes químicos. Os produtos da PCR em heteroduplex formados entre amostras com e sem mutação apresentam despareamento no ponto da mutação que é vulnerável a modi- 


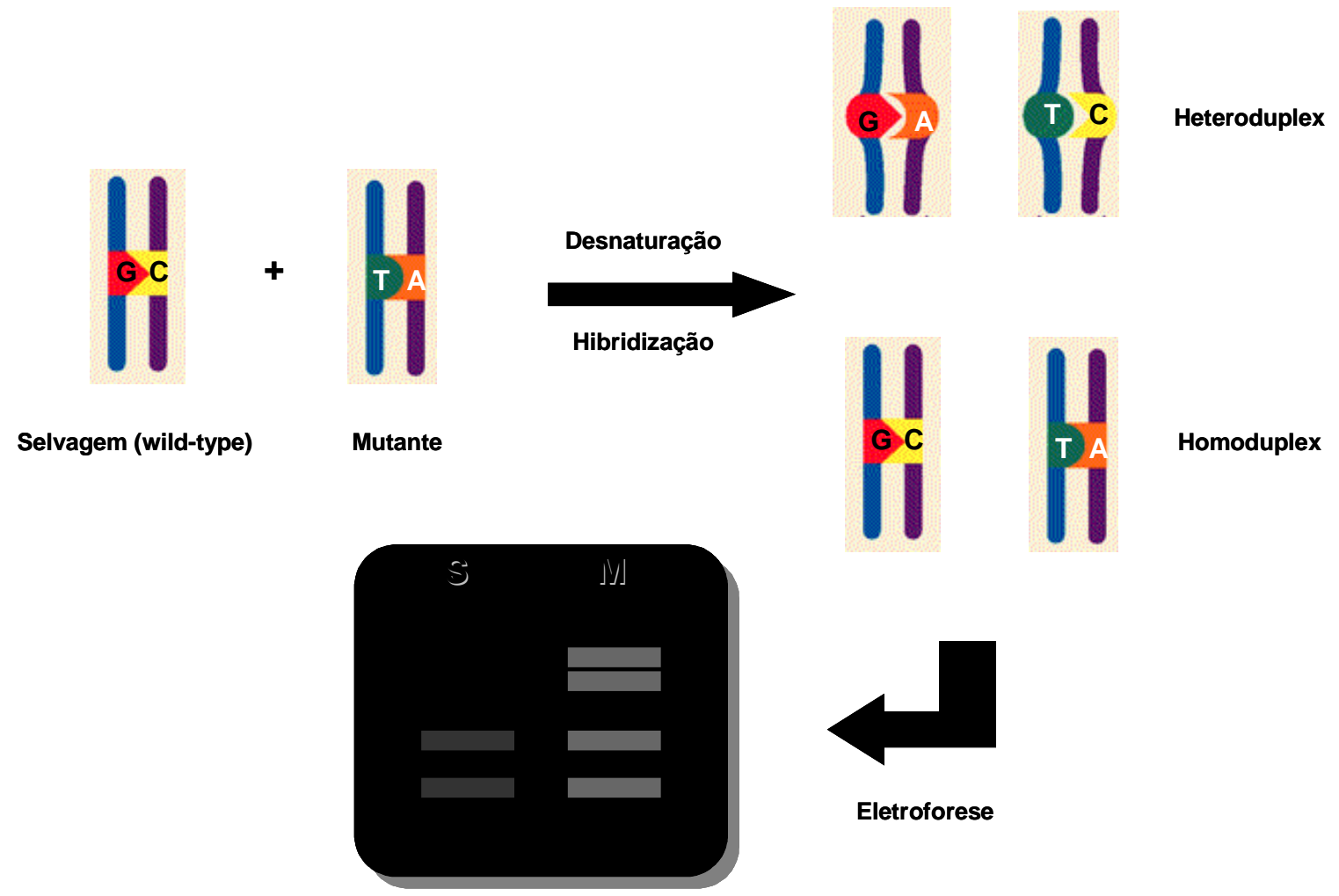

Figura 5. Esquema de triagem de mutações por análise de heteroduplex (HET).

ficações químicas (por exemplo, hidroxilamina modifica citosina não pareada). Os híbridos DNA:DNA formados são clivados pela piperidina em sítios de modificação química (Figura 6). Os pontos de mutação geram fragmentos de clivagem são analisados por eletroforese ${ }^{19,20}$.

Originalmente o método foi descrito para analise de DNA:DNA (heteroduplex), porém, pode também ser aplicado para a analise de DNA:RNA (heteroduplex) ${ }^{20}$. A CCM permite analisar produtos com tamanho superior a $2 \mathrm{~kb}$. Utilizando-se substâncias fluorescentes, uma célula mutante pode ser detectada em dez células normais ${ }^{19}$. O sistema de detecção inicialmente proposto era por marcação dos fragmentos $\operatorname{com}^{32} \mathrm{P}$ ou ${ }^{35} \mathrm{~S}$. Quando pequenas quantidades de alelos mutantes são analisadas na presença de grandes quantidades de alelos comuns, a sensibilidade pode ser aumentada pela separação e detecção de fragmentos marcados com substâncias fluorescentes e detectados num aparelho para seqüenciamento automático ${ }^{21}$.

A vantagem do método CCM é que todos os pontos de mutação são detectados quando as fitas sense e antisense são analisadas. As desvantagens são a utilização de substâncias tóxicas para fazer a clivagem e a limitação do potencial de automação.

\section{5- Teste da proteína truncada (PTT)}

O seqüenciamento do genoma humano despertou grande interesse na área da proteômica. Sistemas de expressão livre das células podem ser utilizados como ligação entre genômica e proteômica pela conversão de seqüências de ácidos nucléicos em proteínas. A aplicação destes sistemas de expressão in vitro para a detecção de mutações é referida como PTT (Protein Truncation Test) ${ }^{22}$. Este método é útil para a detecção de mutações que alteram a fase de leitura (reading frame) da proteína expressa e que gera um produto protéico menor.

O método PTT envolve a transcrição reversa (RT) onde o RNA é utilizado para produzir cDNA (DNA complementar). A seguir, utilizando-se da PCR com um oligonucleotídeo sense que inclui sinal apropriado para transcrição e tradução, é produzido um produto que codifica uma proteína funcional. Acoplando os produtos da PCR com um sistema transcrição e 


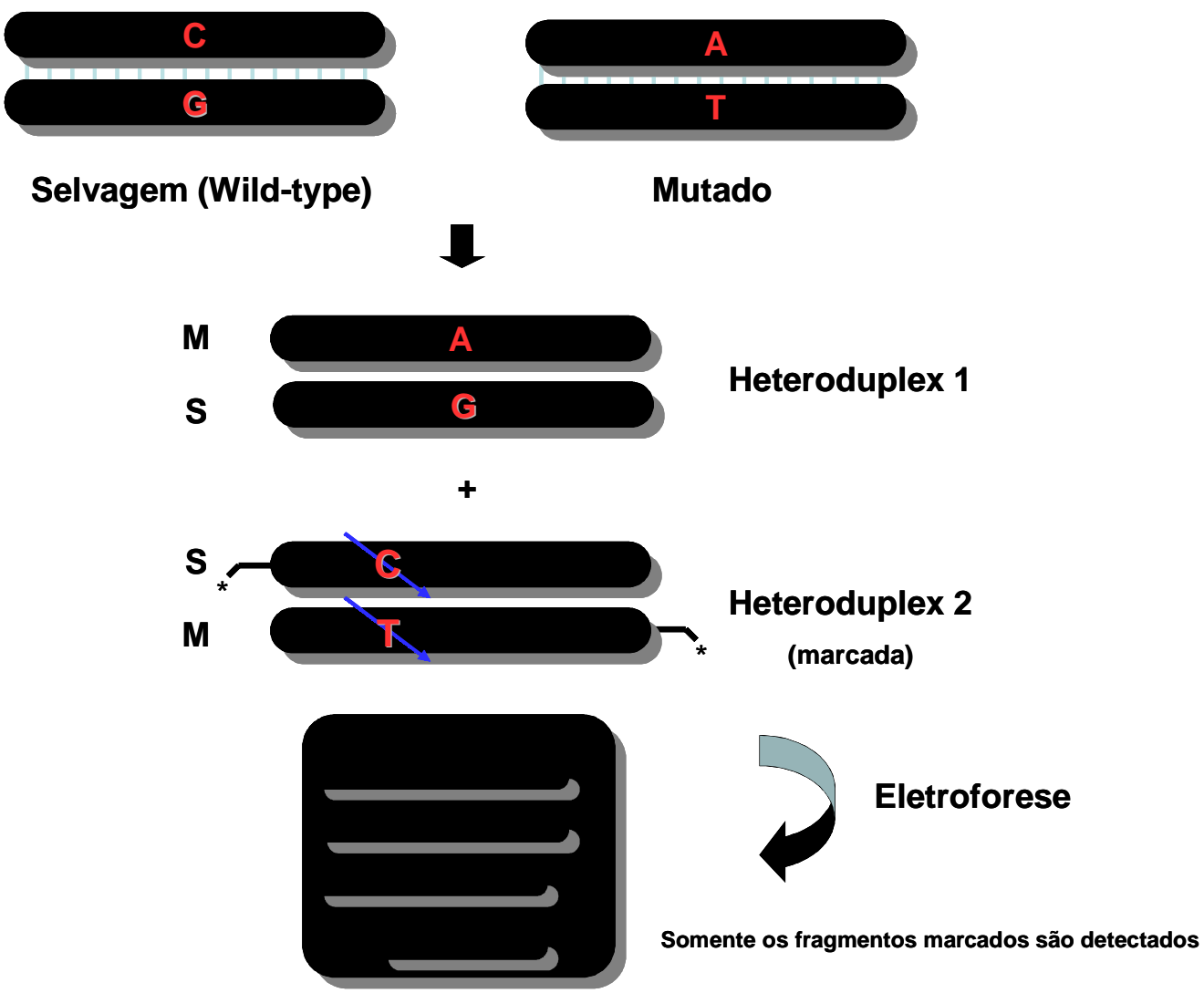

Figura 6. Esquema de triagem de mutações por Clivagem Química.

tradução in vitro, que inclui RNA polimerase, aminoácidos marcados por radiativos, ribossomos e tRNAs, são produzidos peptídeos marcados a partir dos produtos da PCR moldes (Figura 7). Os peptídeos marcados são separados por sistema de eletroforese em gel de poliacrilamida com desnaturante (SDS). A detecção de uma banda, na eletroforese, com menor peso molecular que a proteína natural indica a presença de um polipeptídio truncado que corresponde a uma mutação de fase de leitura que introduziu um códon de parada na seqüência de DNA. A mutação poderá ser confirmada por sequenciamento de DNA.

O método pode iniciar com a transcrição reversa do RNAm e o cDNA resultante amplificado pela PCR. Rearranjos grosseiros e mutações que afetam o processamento do RNA também podem ser detectados pela análise dos produtos da RT-PCR ${ }^{23}$. O tamanho do produto de PCR pode variar entre 4 e $5 \mathrm{~kb}$ com bom desempenho nas reações subseqüentes de transcrição e tradução ${ }^{23}$.

O método PTT é particularmente adequado para genes nos quais a maioria das mutações $(>80 \%)$ resulta em proteínas truncadas ${ }^{23}$. Até o momento, não se conhece qual a relação entre alelos mutantes e normais que pode ser analisada.

Neste sistema poderão aparecer bandas adicionais, provavelmente devido a isoformas que podem complicar a interpretação dos resultados. Portanto, diferenças na mobilidade eletroforética de proteínas truncadas e não truncadas podem ser analisadas visualmente. Desde que PTT envolve certo número de passos (RT-PCR, transcrição e tradução in vitro e eletroforese), um controle positivo interno deve ser incluído.

\section{5- MÉTOdOS DE ESTUdOS DE POLIMOR- FISMOS GENÉTICOS}

A detecção direta de mutações e polimorfismos genéticos de nucleotídeo único (SNPs) é realizada por métodos que permitem a identificação da sequiência de DNA alterada. Esses métodos são também utilizados para confirmação de mutações detectadas por métodos de triagem. Algumas das estratégias mais utilizadas nos estudos de polimorfismos genéticos são descritas neste tópico. 
RNA

\section{Transcrição reversa}

CDNA

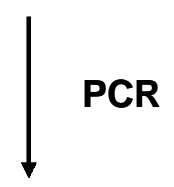

MOLDE - transcrição/tradução

Transcrição/tradução in vitro

Produtos protéicos

Separação das proteinas - SDS-PAGE

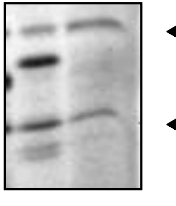

$\longleftarrow$ Selvagem

Mutado

\section{Autorradiografia}

Figura 7. Esquema de triagem de mutações por Teste da Proteína Truncada (PTT).

\section{1- Polimorfismo de tamanhos de fragmentos de restrição (RFLP)}

O RFLP (Restriction Fragment Lenght Polymorphysm) é um método que utiliza enzimas de restrição para detecção de mutações e polimorfismos genéticos ${ }^{24}$. As enzimas de restrição reconhecem sítios específicos na sequiência do DNA que é clivada somente quando o sítio está presente, gerando fragmentos de vários tamanhos que são separados e analisados por eletroforese.

Os tamanhos de fragmentos gerados são muito variáveis. Originalmente este método foi utilizado no Southern Blot para detecção de grandes fragmentos de DNA. Nesta aplicação, o DNA genômico é fragmentado utilizando-se enzimas de restrição e os fragmentos são separados por eletroforese em gel de agarose de alta resolução. Posteriormente os fragmentos de DNA são transferidos a uma membrana de nylon e hibridizados com sondas marcadas que contem sequiências complementares ao loco gênico a ser estudado. Os fragmentos hibridizados são identificados por autorradiografia ou outro sistema de detecção.
Com o advento da PCR e do conhecimento e disponibilidade das seqüências de DNA em bancos genômicos, o método passou a ser utilizado no formato de PCR-RFLP (Figura 8) que permite analisar fragmentos de tamanhos menores ${ }^{25}$. Quando as mutações ou polimorfismos não estão presentes em sítios de restrição, podem ser criados sítios artificiais utilizando-se oligonucleotídeos modificados na PCR. Esta estratégia é denominada mutagenese sitio-dirigida mediada pela $\mathrm{PCR}^{26}$.

Os fragmentos gerados no RFLP podem ser detectados por eletroforese e transferência de DNA como é o Southern blot. No caso da PCR-RFLP, os fragmentos são separados por eletroforese em gel de agarose ou acrilamida e detectados diretamente pela coloração com brometo de etídeo ou outro corante fluorescente como o SYBR Gold® ou ainda por coloração com nitrato de prata. O limite de detecção da PCR-RFLP é de uma célula mutante pode ser detectada entre cinqüenta a cem células normais ${ }^{27}$.

A especificidade do método é de $100 \%$ quando a enzima de restrição apropriada é utilizada. Para o controle de qualidade, amostras de DNA contendo alelos mutantes e comuns devem ser incluídos na aná- 
lise. O método também deve ser ajustado para condições que não permitam que resultados falsos positivos sejam obtidos quando quantidade variável e diferentes proporções de DNA mutante e selvagem estejam sendo analisadas. Resultados questionáveis deverão ser confirmados por repetição dos testes e seqüenciamento de DNA.

\section{2- Amplificação Alelo Oligonucleotideo-Espe- cífica (PCR-ASO)}

A PCR-ASO (Allele Specific Oligonucleotide Amplification) é um método de detecção direta de mutações, também conhecido como ARMS (Amplification Refractory Mutation System). Neste sistema, é utilizado um par de oligonucleotídeos com seqüência específica na extremidade 3' para cada alelo presente no lócus gênico ${ }^{28,29}$. As reações são realizadas separadamente para cada par de oligonucleotídeos (iniciadores da PCR) e apenas os iniciadores que contem a seqüência $100 \%$ complementar ao alelo mutante ou comum possibilitam gerar o produto de PCR específico. A detecção dos produtos da PCR é realizada por eletroforese em gel de agarose. Heterozigotos e homozigotos podem ser discriminados em um único ensaio da PCR quando diferentes alelos são amplificados utilizando-se marcados com diferentes fluorocromos como é o caso da PCR em tempo real ${ }^{30}$.

A especificidade da reação é influenciada por variações nas concentrações dos reagentes (magnésio, oligonucleotídeos, desoxirribonucleotídeos, DNA e DNA polimerase), temperatura e tempo de hibridi-

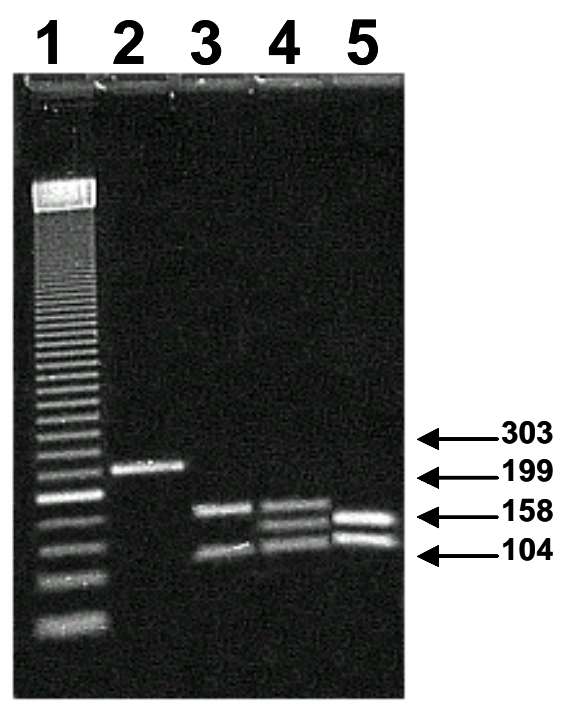

Figura 8. Perfis de RFLP obtidos por eletroforese em gel de agarose a $2 \%$ corado com brometo de etídeo de produtos de PCR digeridos com a enzima Nla III. Produto de PCR (coluna 2). Genótipos: CC (coluna 3); CT (coluna 4) e TT (coluna 5). Marcador de pares de bases de DNA de 50 bp (coluna 1).

zação e número de $\operatorname{ciclos}^{31}$. A adição de formamida pode reduzir a geração de produtos inespecíficos. Condições de baixa estringência na PCR propiciam a hibridização e extensão dos iniciadores nas seqüências de ambos os alelos que levam a geração de resultados incorretos. A especificidade é crítica quando a freqüência do alelo mutante é baixa ou desconhecida.

A possibilidade de resultados falso-positivo ou falso-negativo é a principal limitação do método. Fal-
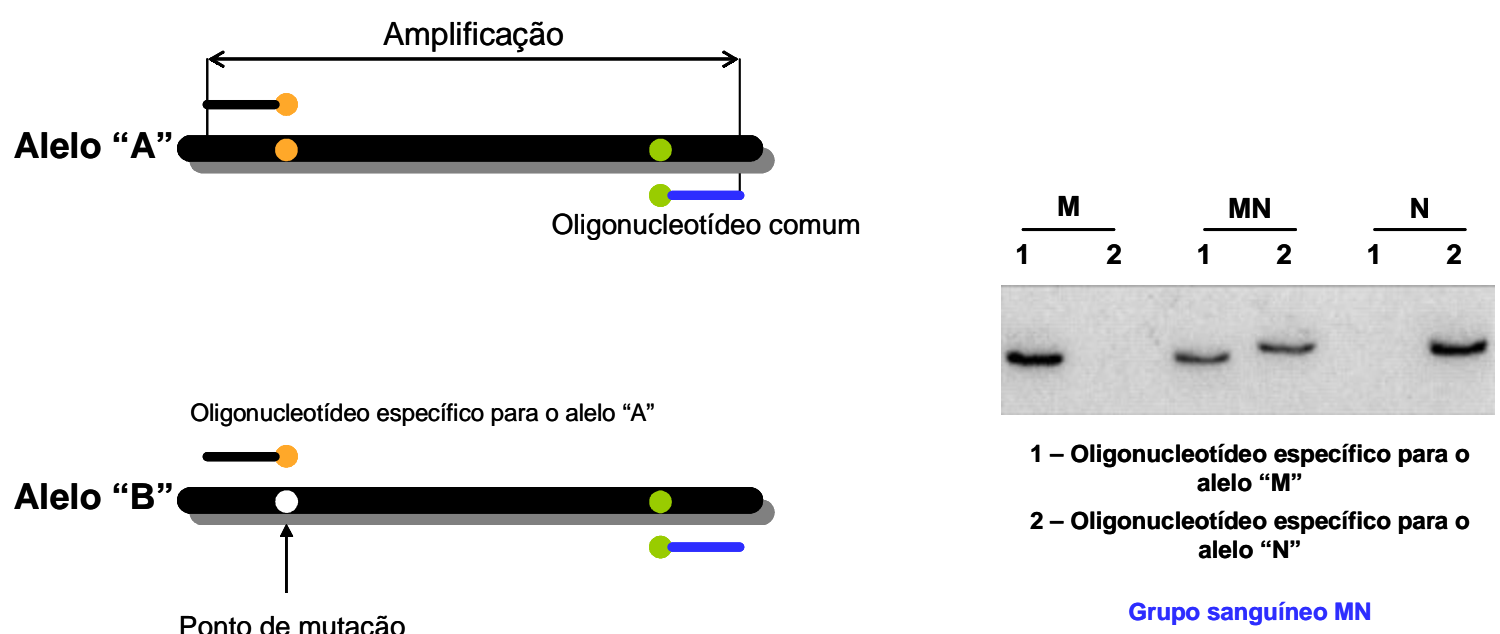

Figura 9. Esquema de detecção de mutações pela PCR Alelo Oligonucleotideo-Específico (PCR-ASO). 
so-positivo pode resultar de contaminação ou de extensão incorreta pela DNA polimerase. Para a exclusão de resultados falsos, as condições de reação devem ser otimizadas e a concentração do DNA de interesse deve ser definida e precisamente controlada. A utilização de controles deve ser realizada para excluir resultados indesejados. A utilização de controle interno na PCR-ASO é importante para excluir resultados falsos negativos principalmente para a identificação de heterozigotos.

\section{2- PCR em tempo real}

$\mathrm{Na}$ PCR em tempo real (Real-time PCR) são utilizadas pequenas sondas de DNA marcadas nas ex-

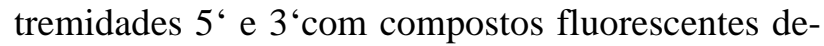
nominados reporter (marcador) e quencher (bloqueador), respectivamente ${ }^{32,33}$. As sondas são construídas de maneira a hibridizar perfeitamente com um alelo especifico em um determinado lócus, porém, de forma incompleta com outro alelo.

No sistema TAqMan ${ }^{\circledR}$, o fluoróforo bloqueador está próximo do marcador, bloqueando a emissão do sinal fluorescente ${ }^{32}$. Na fase de extensão da PCR, a atividade exonuclase 5' e 3' da DNA polimerase é responsável pela digestão da sonda, o marcador é liberado distanciando-se do bloqueador e a fluorescência é emitida (Figura 10). As sequiências de iniciadores e sondas, assim como as condições de PCR devem ser muito bem estabelecidas para evitar pareamentos incorretos durante as etapas de hibridização e extensão na PCR em tempo real.

\section{3- Arranjos de DNA}

Os arranjos de DNA (DNA Arrays) foram concebidos para ampliar e agilizar as análises genômicas. O microarray é a forma miniaturizada de arranjos em que os fragmentos de genes estão fixos em uma lâmina de vidro ${ }^{34}$. Também é conhecido como bioship ou ship biológico ${ }^{35}$.

As análises das atividades gênicas e a identificação de mutações e polimorfismos são realizadas de forma sistematizada usando o princípio da hibridização de DNA. As sequiências de genes que contem mutações conhecidas são fixadas na matriz de vidro (sondas de captura). Produtos da PCR são gerados utilizando-se iniciadores específicos marcados com fluoróforos. A seguir os produtos da PCR são hibridizados com as sondas capturadas na matriz de vidro e os arranjos de sinais fluorescentes são medidos utilizando-se um sistema ultra-rápido de detecção de fluorescência e a intensidade de cada ponto é determinada. A localização do ponto associado com a sua intensidade determina a sequiência e a quantidade de material presente na amostra. Estes dados são processados por programas sofisticados de computadores que possibilitarão a analise refinada dos resultados.

A possibilidade de se colocar milhares de sequiências em uma única lâmina de arranjo possibilita a obtenção de informações do genoma inteiro em um único ensaio, identificando milhões mutações e polimorfismos simultaneamente ${ }^{35}$. Comercialmente já estão disponíveis, em bioships, conjuntos de polimorfis-

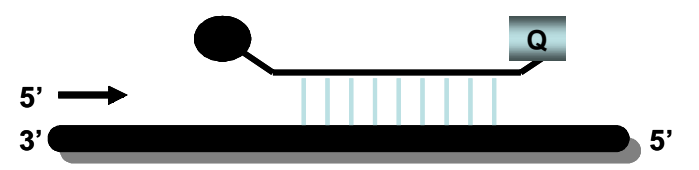

Alelo "A"

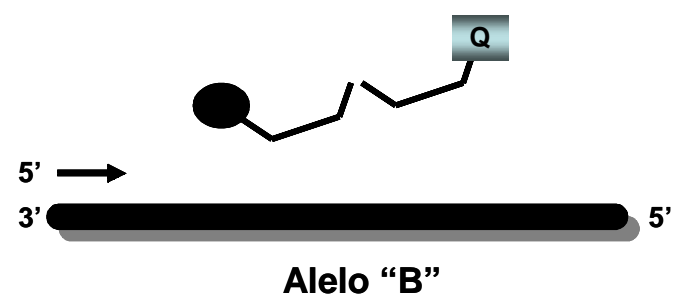

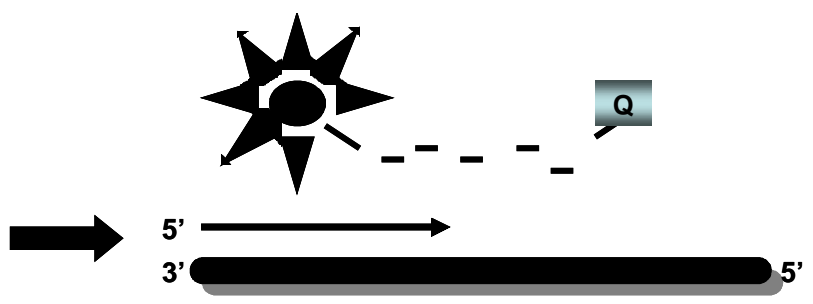

Alelo "A"

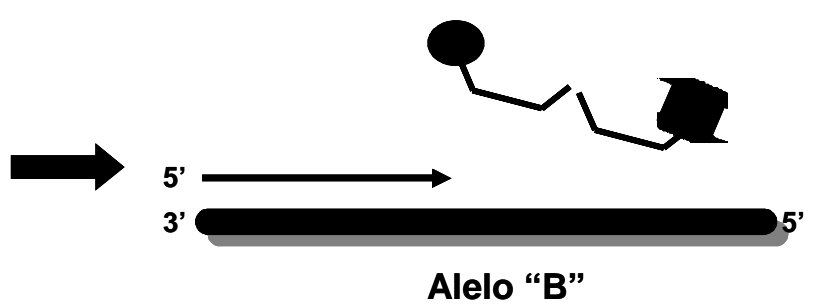

Figura 10. Esquema de detecção de mutações pela PCR em tempo real. 
mos e ou mutações para fins de estudos farmacogenéticos do sistema citocromo P450 para cada grupo de fármacos potencialmente importantes, assim como para diagnóstico de alterações genéticas de utilidade terapêutica na clinica médica ${ }^{36}$.

\section{6- CONSIDERAÇÕES FINAIS}

Nesta revisão foram abordados métodos moleculares que podem ser utilizados nos estudos farmacogenéticos. Foram apresentados os métodos utilizados na obtenção de ácidos nucléicos e na detecção mutações e polimorfismos genéticos, indicando suas especificações, aplicações e limitações.

Alguns desses métodos podem ser aplicados para estudos de alterações genéticas em larga escala. A análise do enorme conjunto de resultados gerados por esses métodos é dependente da Bioinformática que tornou-se uma ciência imprescindível no desenvolvimento da tecnologia molecular com a integração das ciências da saúde, biológicas e da computação. A simulação "in silico" é uma ferramenta potencialmente importante na formulação de reações e de interações medicamento-proteína, proteína-DNA, medicamento-DNA e outras possibilidades que estão envolvidas na eficácia e na segurança terapêutica dos medicamentos.

Com os avanços crescentes da tecnologia molecular e bioinformática tem sido possível aplicar os conhecimentos gerados pelos estudos farmacogenômicos, transcriptômicos e proteômicos na investigação de novos alvos terapêuticos. Esses conhecimentos permitirão, em futuro próximo, aplicação da terapia individualizada que melhorarão significativamente a atenção médica e farmacêutica e, conseqüentemente, a qualidade de vida das pessoas.

Hirata MH, Tavares V, Hirata RDC. From Molecular Biology to Medicine: methods commonly used in pharmacogenetics. Medicina (Ribeirão Preto) 2006; 39 (4): 522-34.

ABSTRACT: In this review, we discussed the procedures for obtaining, handling and storage of biological samples useful in molecular tests. Methods for screening and direct detection of mutations and gene polymorphisms were presented. Principles, strategies, applications and limitations of polymerase chain reaction (PCR) variations, such as denaturing gradient gel electrophoresis (DGGE), single strain conformational polymorphism (SSCP), restriction fragment length polymorphism (RFLP), allele oligonuleotide-specific amplification (PCR-ASO), Real time PCR, DNA arrays and other molecular techniques, were commented.

Keywords: Pharmacogenetics. Polymerase Chain Reaction. Polymorphism, Single-Stranded Conformational. Polymorphism, Restriction Fragment Length. DNA Arrays. Denaturing Gradient Gel Electrophoresis.

\section{REFERÊNCIAS}

1 - Thornton M, Gladwin A, Payne R, Moore R, Cresswell C, McKechnie D, Kelly S, March R. Automation and validation of DNA-banking systems. Drug Discov Today 2005; 10: 136975.

2 - Sambrook J, Russell DW. Molecular cloning: a laboratorial manual, 3rd ed. New York: Cold Spring Harbor Laboratory Press; 2001. 3 v.

3 - Salazar LA, Hirata MH, Cavalli SA, Machado MO, Hirata RD. Optimized procedure for DNA isolation from fresh and cryopreserved clotted human blood useful in clinical molecular testing. Clin Chem 1998; 44: 1748-50.
4 - Mullis K, Faloona F, Scharf S, Saiki R, Horn G, Erlich H. Specific enzymatic amplification of DNA in vitro: the polymerase chain reaction. 1986. Biotechnology 1992; 24: 17-27.

5 - Reiss J, Krawczak M, Schloesser M, Wagner M, Cooper DN The effect of replication errors on the mismatch analysis of PCR-amplified DNA. Nucleic Acids Res 1990; 18: 973-8.

6 - Sanger F, Nicklen S, Coulson AR. DNA sequencing with chainterminating inhibitors. Proc Natl Acad Sci U S A 1977; 74: 5463-7.

7 - Myers RM, Lumelsky N, Lerman LS, Maniatis T. Detection of single base substitutions in total genomic DNA. Nature 1985 313: $495-8$. 
8 - Myers RM, Fischer SG, Maniatis T, Lerman LS. Modification of the melting properties of duplex DNA by attachment of a GC-rich DNA sequence as determined by denaturing gradient gel electrophoresis. Nucleic Acids Res 1985; 13: 311129.

9 - Knapp LA. Denaturing gradient gel electrophoresis and its use in the detection of major histocompatibility complex polymorphism. Tissue Antigens 2005; 65: 211-9.

10 - Orita M, Iwahana H, Kanazawa H, Hayashi K, Sekiya T. Detection of polymorphisms of human DNA by gel electrophoresis as single-strand conformation polymorphisms. Proc Natl Acad Sci USA 1989; 86: 2766-70.

11 - Sarkar G, Yoon HS, Sommer SS. Screening for mutations by RNA single-strand conformation polymorphism (rSSCP): comparison with DNA-SSCP. Nucleic Acids Res 1992; 20 : 871-8.

12 - Kurvinen K, Hietanen S, Syrjanen K, Syrjanen S. Rapid and effective detection of mutations in the p53 gene using nonradioactive single-strand conformation polymorphism (SSCP) technique applied on PhastSystem. J Virol Methods 1995; 51: 43-53.

13 - Sheffield VC, Beck JS, Kwitek AE, Sandstrom DW, Stone EM. The sensitivity of single-strand conformation polymorphism analysis for the detection of single base substitutions. Genomics 1993; 16: 325-32.

14 - Broly F, Marez D, Sabbagh N, Legrand M, Millecamps S, Lo Guidice JM et al. An efficient strategy for detection of known and new mutations of the CYP2D6 gene using single strand conformation polymorphism analysis. Pharmacogenetics 1995; 5: 373-84.

15 - Salazar LA, Hirata MH, Hirata RD. Increasing the sensitivity of single-strand conformation polymorphism analysis of the LDLR gene mutations in brazilian patients with familial hypercholesterolemia. Clin Chem Lab Med 2002; 40: 441-5.

16 - White MB, Carvalho M, Derse D, O'Brien SJ, Dean M. Detecting single base substitutions as heteroduplex polymorphisms. Genomics 1992; 12: 301-6.

17 - Tchernitchko D, Lamoril J, Puy H, Robreau AM, Bogard C, Rosipal R, Gouya L, Deybach JC, Nordmann Y.. Evaluation of mutation screening by heteroduplex analysis in acute intermittent porphyria: comparison with denaturing gradient gel electrophoresis. Clin Chim Acta 1999; 279:133-43.

18 - Tian H, Brody LC, Landers JP. Rapid detection of deletion, insertion, and substitution mutations via heteroduplex analysis using capillary- and microchip-based electrophoresis. Genome Res 2000; 10: 1403-13.

19 - Saleeba JA, Ramus SJ, Cotton RG. Complete mutation detection using unlabeled chemical cleavage. Hum Mutat 1992; 1 : 63-9.

20 - Cotton RG. Mutation detection by chemical cleavage. Genet Anal 1999; 14: 165-8.

21 - Verpy E, Biasotto M, Meo T, Tosi M. Efficient detection of point mutations on color-coded strands of target DNA. Proc Natl Acad Sci USA 1994; 91: 1873-7.
22 - Roest PA, Roberts RG, Sugino S, van Ommen GJ, den Dunnen JT. Protein truncation test (PTT) for rapid detection of translation-terminating mutations. Hum Mol Genet 1993; 2: 171921.

23 - Den Dunnen JT, Van Ommen GJ. The protein truncation test: A review. Hum Mutat 1999; 14: 95-102.

24 - Vas A. Polymerase chain reaction and other gene techniques in pharmacogenetics: an introduction and review. Acta Physiol Hung 1992; 79: 253-60.

25 - Shi MM. Enabling large-scale pharmacogenetic studies by high-throughput mutation detection and genotyping technologies. Clin Chem 2001; 47: 164-72.

26 - Cavalli SA, Hirata MH, Hirata RD. Detection of Mboll polymorphism at the 5 ' promoter region of CYP3A4. Clin Chem 2001; 47: 348-51.

27 - Chen J, Viola MV. A method to detect ras point mutations in small subpopulations of cells. Anal Biochem 1991; 195: 516.

28 - Heim M, Meyer UA. Genotyping of poor metabolisers of debrisoquine by allele-specific PCR amplification. Lancet 1990; 336: 529-32.

29 - Newton CR, Graham A, Heptinstall LE, Powell SJ, Summers C, Kalsheker N, Smith JC, Markham AF. Analysis of any point mutation in DNA. The amplification refractory mutation system (ARMS). Nucleic Acids Res 1989; 17: 2503-16.

30 - Okayama N, Fujimura K, Nakamura J, Suehiro Y, Hamanaka $Y$, Hinoda Y. Evaluation of a new efficient procedure for single-nucleotide polymorphism genotyping: tetra-primer amplification refractory mutation system-polymerase chain reaction. Clin Chem Lab Med 2004; 42: 13-6.

31 - Sohda T. Allele-specific polymerase chain reaction for genotyping human cytochrome P450 2E1. J Clin Lab Anal 1999; 13: 205-8.

32 - Whitcombe D, Brownie J, Gillard HL, McKechnie D, Theaker J, Newton CR, Little S. A homogeneous fluorescence assay for PCR amplicons: its application to real-time, single-tube genotyping. Clin Chem 1998; 44: 918-23.

33 - Hiratsuka M, Sasaki T, Mizugaki M. Genetic testing for pharmacogenetics and its clinical application in drug therapy. Clin Chim Acta 2006; 363: 177-86.

34 - Huang JX, Mehrens D, Wiese R, Lee S, Tam SW, Daniel S, Gilmore J, Shi M, Lashkari D. High-throughput genomic and proteomic analysis using microarray technology. Clin Chem 2001; 47: 1912-6.

35 - Jain KK. Applications of biochips: from diagnostics to personalized medicine. Curr Opin Drug Discov Devel 2004; 7: 285-9.

36 - Wick I, Hardiman G. Biochip platforms as functional genomics tools for drug discovery. Curr Opin Drug Discov Devel 2005; 8: 347-54. 